$\begin{array}{ll}\text { Abstracta Iranica } & \begin{array}{l}\text { Abstracta Iranica } \\ \text { Revue bibliographique pour le domaine irano-aryen }\end{array} \\ & \text { Volume } \mathbf{2 7} \mid \mathbf{2 0 0 6} \\ & \text { Comptes rendus des publications de } \mathbf{2 0 0 4}\end{array}$

\title{
Slaves of the Shah: New Elites of Safavid Iran. London, Tauris, 2004, 256 p.
}

\section{Christoph Werner}

\section{(2) OpenEdition}

1 Journals

\section{Édition électronique}

URL : http://journals.openedition.org/abstractairanica/5938

DOI : $10.4000 /$ abstractairanica.5938

ISSN : 1961-960X

Éditeur :

CNRS (UMR 7528 Mondes iraniens et indiens), Éditions de l'IFRI

\section{Édition imprimée}

Date de publication : 15 mai 2006

ISSN : 0240-8910

\section{Référence électronique}

Christoph Werner, «Slaves of the Shah: New Elites of Safavid Iran. London, Tauris, 2004, 256 p. », Abstracta Iranica [En ligne], Volume 27 | 2006, document 163, mis en ligne le 02 janvier 2007, consulté le 25 septembre 2020. URL : http://journals.openedition.org/abstractairanica/5938 ; DOI : https:// doi.org/10.4000/abstractairanica.5938

Ce document a été généré automatiquement le 25 septembre 2020.

Tous droits réservés 


\title{
Slaves of the Shah: New Elites of Safavid Iran. London, Tauris, 2004, $256 \mathrm{p}$.
}

\author{
Christoph Werner
}

1 The later Safavid period, hitherto seen as a period of decline that could be generously neglected, has lately received a growing interest. of special interest is the role of the new slave elites that played an increasingly important role in the fabric of Safavid rule from Šāh 'Abbās onwards. The present book, a joint production by four leading Safavid scholars teaching and working at American universities, is a highly welcome contribution to this new and exciting field. Presented as a coherent monograph, the different chapters are not signed individually, although it is not difficult to assign them to their respective authors, since they frequently refer to themselves or their publications in the first person.

2 The institution of the gulāmān-i Hāșșa-yi šarifa, the slaves of the imperial household, is placed into the wider context of Islamic concepts of slavery and state building in the introductory chapter. It is further elaborated by Babayan in the second chapter, where the close links between royal concubines, eunuchs of the harem and administrative posts held by guläms are analyzed. The use of the term "slave" is however used unevenly by the contributors; the other authors seem less comfortable with it and prefer the indigenous appellation of guläm or coin expressions such as "ghulamhood". This is a clear hint that the Safavid institution is quite different from the Mamluk or Ottoman states and needs further comparative discussion. The third chapter by Baghdiantz-McCabe delineates the relations between the Julfan Armenians and the $\dot{g}$ uläms and highlights their role as the Shah's merchants and financiers. The last two chapters shift the focus to art history and add considerable depth to the perspective on slave elites. Babaie treats architectural patronage exercised by leading gulāms of the Safavid court that was closely modeled on royal projects such as the complex in Kirman by Ganj-'Alī Hān that is compared to Šāh 'Abbās great maydān of Isfahan. The last chapter by Farhad, perhaps the most coherent and innovative contribution of the 
volume, presents $\dot{g} u l a \overline{m s}$ as important collectors of art and as individuals that commissioned highly original illustrated manuscripts, emulating and supporting royal patronage of the arts. A conclusion that would summarize the authors' findings is unfortunately absent.

INDEX

Thèmes : 4.2.1. Safavides et Qâjârs

\section{AUTEURS}

CHRISTOPH WERNER

Université de Freiburg im Brisbau 